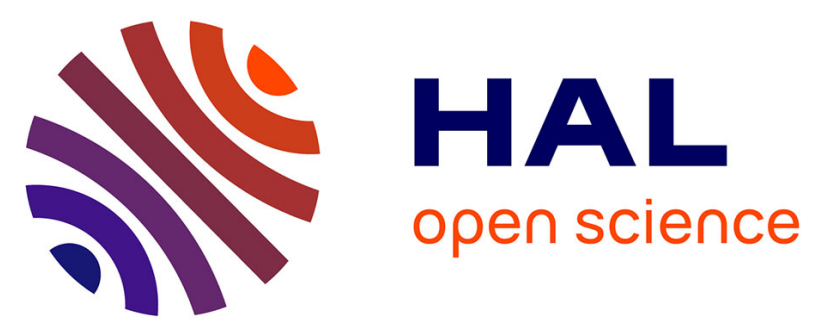

\title{
Absence of protective role of afferent nerves in early intestinal mucosal alterations induced by abdominal irradiation in rats
}

C. Picard, J. Wysocki, Christine Linard, Rafael Garcia Villar, Lionel Bueno, N.M. Griffiths, Jean Fioramonti

\section{To cite this version:}

C. Picard, J. Wysocki, Christine Linard, Rafael Garcia Villar, Lionel Bueno, et al.. Absence of protective role of afferent nerves in early intestinal mucosal alterations induced by abdominal irradiation in rats. International Journal of Radiation Biology, 2001, 77 (3), pp.349-356. hal-02674028

\section{HAL Id: hal-02674028 \\ https://hal.inrae.fr/hal-02674028}

Submitted on 31 May 2020

HAL is a multi-disciplinary open access archive for the deposit and dissemination of scientific research documents, whether they are published or not. The documents may come from teaching and research institutions in France or abroad, or from public or private research centers.
L'archive ouverte pluridisciplinaire HAL, est destinée au dépôt et à la diffusion de documents scientifiques de niveau recherche, publiés ou non, émanant des établissements d'enseignement et de recherche français ou étrangers, des laboratoires publics ou privés.

\section{다(1)(2)}

Distributed under a Creative Commons Attribution - ShareAlikel 4.0 International 


\title{
Absence of protective role of afferent nerves in early intestinal mucosal alterations induced by abdominal irradiation in rats
}

\author{
C. PICARD* ${ }^{\dagger}$, J. WYSOCKI $\dagger$, G. LINARD $\dagger$, R. GARCIA-VILLAR \\ N. M. GRIFFITHS $\dagger$ and J. FIORAMONTI*
}

(Recived 7 fune 2000; accepted 22 August 2000)

\begin{abstract}
.
Purpose: To assess the early effects of primary afferent nerve suppression by systemic treatment with the neurotoxin capsaicin in an acute model of abdominal irradiation in rats $(10 \mathrm{~Gy}$, gamma).

Materials and methods: Changes in myeloperoxidase (MPO) activity, calcitonin gene-related peptide (CGRP) tissue content, number of mast cells and apoptotic cells were determined in jejunum and ileum in four groups of rat male Wistar (vehicle shamirradiated, vehicle irracliated, capsaicin sham-irradiated and capsaicin irradiated) at 1 and 3 days post-irradiation.

Results: In vehicle irradiated rats, GGRP was significantly increased from the first day after irradiation in jejunal mucosa; MPO activity increased in both segments at day 3 but not at day 1 after irradiation; the number of detectable mucosal mast cells dropped to nearly zero on days 1 and 3, while the apoptotic cells in the intestinal mucosa were significantly increased at day 1. Similar results were obtained for mast cells and apoptosis in capsaicin irradiated rats as compared to capsaicin shamirradiated rats, while MPO activity was significantly increased and CGRP concentration in jejunal mucosa significantly clecreased from the first day in thesc rats in comparison with capsaicin sham-irradiated rats.

Conclusions: Intestinal sensory innervation seems not to have a major protcctive role against a radiation-induced intestinal inflammatory reaction.
\end{abstract}

\section{Introduction}

Application of local doses of ionizing radiation for radiotherapy of abdominal and pelvic malignancies leads to acute gastrointestinal symptoms seen within hours to days, as well as to chronic radiation enteropathy within months to years (Yeoh et al. 1993). Acute radiation enteritis is characterized by diarrhea, nausea and vomiting while chronic enteropathy is dominated by haemorrhage and ulceration. The origin of these symptoms is not clear but they are classically attributed to the breakdown of epithelial integrity associated with a decrease in water absorption combined with excessive secretion and loss of sodium and chloride, leading

*Author for correspondence; e-mail: celine.picard@ipsn.fr

$\uparrow$ Institut de Protcction et de Sureté Nucléaire, Digestive Radiobiology Unit, $\mathrm{BP} \mathrm{n}^{\circ}$ 6, 92265 Fontcnay-aux-Roses, France.

+Institut National de la Recherche Agronomique, NeuroGastroenterology \& Nutrition Unit, BP n ${ }^{\circ} 3,31931$ Toulousc Gedcx, France. to diarrhea and electrolyte imbalance following both whole body (Gunter-Smith 1986) and abdominal irradiation (Empey et al. 1992, Chun et al. 1997). This mucosal breakdown is preceded by an acute inflammatory response which appears by $4-8 \mathrm{~h}$ after abdominal irradiation and has been identified with parameters such as increased microvascular permeability, significant mucosal infiltration of neutrophils or oedema of lamina propria (Buell and Harding 1989). Some studies also reported the effects of both total body or abdominal irradiation on mast cell degranulation (Harari et al. 1994, Sedgwick and Ferguson 1994), and which suggested a role for mast cell mediators in the inflammatory response.

It has been reported that abdominal irradiation induces early neurally mediated intestinal responscs. For example, abdominal intestinal motor patterns such as giant migrating contractions or retrograde giant contractions occur a few hours after irradiation in dogs (Erickson et al. 1994). In the rat colon, neurally evoked electrolyte transport has been found to be dramatically reduced on the first day after exposure to ionizing radiation (François et al. 1998). These alterations of intestinal neural functions are supported by increased expression of transmitters of neural affcrents, such as substance $\mathrm{P}(\mathrm{SP})$, after whole body irradiation (Esposito et al. 1996) and vasoactive intestinal peptide (VIP) and substance $\mathrm{P}$ after irradiation of upper abdomen in rats (Hockerfelt et al. 2000). Furthermore, an increase in GGRP-immunoreactive nerve fibres has been also reported after whole body irradiation in rats (Zhang el al. 1998). Other authors have demonstrated modifications in neural functions after different modes of irradiation in buman studies, suggesting a significant role for nerves in inflammatory response of radiation-induccd enteropathy. Radiotherapy of the abdominal sphere has been shown to modify the innervation of the lamina propria in human bowcl (Hirschowitz and Rode 1991) as well as to increase colonic immunohistochemical expression of VIP and SP (Hockerfelt et al. 1999, Forsgren et al. 2000). It is interesting that little attention has been given to the effects of ionizing 
radiation on the neural control of intestinal function even though this was suggested over 40 years ago (Conard 1956).

A role for the neurotransmitters of sensory afferents, such as tachykinins or calcitonin gene-related peptide (CGRP), in the control of intestinal inflammation is now accepted (Sharkey 1992, Maggi 1997). Despite some conflicting reports, it is well established that capsaicin-sensitive afferents play a protective role against experimental intestinal inflammation in animals (Reinshagen et al. 1996, McCafferty et al. 1997, Mazelin et al. 1998a, Holzer 1998). In addition, a proinflammatory role of sympathetic nerves has been shown (McCafferty et al. 1997). GGRP is released from sensory nerve fibres in the gut wall during the time course of experimental colitis in animals (Eysselein et al. 1992, Keates et al. 1998) and in inflammatory bowel disease in humans (Eysselein et al. 1992). However, in contrast to the effects observed with tachykinin receptor antagonists (Mazelin et al. 1998b), CGRP receptor antagonists have been found to aggravate (Reinshagen et al. 1998) and CGRP to decrease (Mazelin et al. 1999) the severity of experimental colitis, suggesting that CGRP exerts mucosal protection during intestinal inflammation. Since early intestinal alterations induced by abdominal irradiation involve both inflammatory and neuronal pathways, the question arises as to whether sensory afferents play a role in these alterations.

The aim of this study was to determine whether capsaicin-sensitive denervation modifies some parameters which are characteristic of the early mucosal altcrations induced by abdominal irradiation in jejunum and ileum in rats. In addition tissue concentrations of CGRP, a mediator characteristic of capsaicin-sensitive afferents (Sternini et al. 1987), were measured in tissue extracts of intestinal wall.

\section{Materials and methods}

\subsection{Animals}

Experiments were performed in male Wistar rats (Janvier, Le Genest Saint Isle, France) initially weighing 200-250 g. Rats were housed under controlled lighting conditions, with standard diet (Usine d'Alimentation Rationnelle, Epinay-sur-Orge, France) and water provided ad libitum. All protocols were conducted according to the French regulations for animal experimentation (Ministry of Agriculture, Act 87-848, 19 October 1987).

\subsection{Capsaicin treatment}

Sensory denervation was performed according to the protocol described by Holzer (Holzer 1991). Rats were injected subcutaneously on 4 consecutive days with capsaicin (Sigma Chemical, St QuentinFallavier, France; $40 \mathrm{mmol} / \mathrm{l}$ in $80 \% \mathrm{NaCl} 0.9 \%$, $10 \%$ ethanol and $10 \%$ tween 80 ). A total dose of $125 \mathrm{mg} / \mathrm{kg}$ was administered under anaesthesia (ketamine $60 \mathrm{mg} / \mathrm{kg}$, ip; xylazine $5 \mathrm{mg} / \mathrm{kg}$, ip) in doses of $10,25,40$ and $50 \mathrm{mg} / \mathrm{kg}$ on days $1-4$, respectively. Control animals received equal volumes of vehicle. The effectiveness of capsaicin treatment was assessed according to Gamse (Gamse 1982) by means of the eye-wiping test, which consists of impaired chemosensitivity of corneal afferents to one drop of $1 \% \mathrm{NH}_{4} \mathrm{OH}$ instilled into the eye. Animals treated with capsaicin that showed any wiping movement were excluded from the study. Capsaicin-treated and vehicle-treated animals were irradiated 10 days after treatment.

\subsection{Iradiation protocol}

Rats were exposed to abdominal gamma $\left({ }^{60} \mathrm{Co}\right.$ source, $3900 \mathrm{Ci}$ ) irradiation with a single dose of $10 \mathrm{~Gy}(0.96 \mathrm{~Gy} / \mathrm{min})$ under anaesthesia induced by pentobarbital $(60 \mathrm{mg} / \mathrm{kg}$; i.p.). The irradiation source was placed in the vertical position and collimated to delimit an irradiation field $(6 \mathrm{~cm})$ and animals were irradiated in a zone comprised between xyphoid cartilage and iliac crests. Sham-irradiated rats were anaesthetiscd in the same conditions but not exposed to the radioactive source.

Four groups of rats (six rats in each group) were examined and sacrificed 1 and 3 days postirradiation: vehicle sham-irradiated, vehicle irradiated, capsaicin sham-irradiated and capsaicin irradiated groups.

\subsection{Histological study}

Two pieces $(5 \mathrm{~mm})$ of both jejunum and ileum were taken from each rat at $10 \mathrm{~cm}$ from the ligament of Treitz and $5 \mathrm{~cm}$ from the ileo-cecal junction, respectively. Tissues were fixed in $10 \%$ neutralized formalin and Carnoy's solution, respectively. 'The samples were cleared in a vacuum infiltration processor, embedded in paraffin blocks and $5 \mu \mathrm{m}$ sections were made with a rotating microtome. Formalin fixative was used for routine histological analysis with hematoxylin and eosin staining, whereas Carnoy's fixative was used for identification of intestinal mast cells with Alcian blue-Safranin O staining (Roberts et al. 1990). The number of mucosal mast cells was determined under a light microscope $(\times 40$ objective) within 10 randomly selected fields of the mucosa (Wallace et al. 1992). The number of apoptotic cells in the crypts of small intestine was determined on hematoxylin and eosin stained sections. The number 
of apoptotic cells were counted over complete sections (between 100-200 crypts) and data are expressed as the number of apoptotic cells per 50 whole crypts per animal in order to standardize the procedure (Merritt et al. 1996, Potten and Grant 1998). Histological analyses were carried out by a pathologist (Dr J. Pomiès, Histotox, La Rochelle, France) who was unaware of the treatment groups.

\subsection{MPO activity measurement}

Intestinal segments $(8-10 \mathrm{~mm}$ in length) adjacent to those used for microscopic evaluation were rinsed and stored at $-80^{\circ} \mathrm{C}$ for no more than one week. MPO activity was determined using the method of Bradley et al. (1982). Briefly, samples were homogenized with a T25 Ultraturrax in phosphate buffer (50 mm, pH 6.0), snap-frozen and thawed three times, and centrifuged for $15 \mathrm{~min}$ at $8000 \mathrm{~g}$ at $4^{\circ} \mathrm{C}$. The pellets were sonicated with $500 \mu 1$ of hexadecyl trimethylammonium bromide (HTAB $0.5 \%, \mathrm{w} / \mathrm{v}$, in $50 \mathrm{~mm}$ phosphate buffer). After centrifugation for $15 \mathrm{~min}$ at $8000 \mathrm{~g}$ at $4^{\circ} \mathrm{C}, 100 \mu \mathrm{l}$ of supernatant was mixed with $3 \mathrm{ml}$ of buffer containing phosphate buffer $50 \mathrm{~mm}$, $0.167 \mathrm{mg} / \mathrm{ml}$ of o-dianisidine dihydrochloride and $0.0005 \%$ hydrogen peroxide. Absorbance at $450 \mathrm{~nm}$ was determined with a spectrophotometer (DU-640, Beckman, Gagny, France) for 2 min. One unit of MPO was defined as the quantity catalysing the decomposition of $1 \mu \mathrm{mol}$ of hydrogen peroxide to water per minute at $25^{\circ} \mathrm{C}$. MPO from human leukocytes was used as standard. Protein content was measured by absorbance at $750 \mathrm{~nm}$ with a Bio-Rad protein assay kit (Bio-Rad, Ivry sur Seine, France). $\mathrm{MPO}$ activity was expressed in units per gram of protein.

\subsection{Radioimmunoassay for $C G R P$}

GGRP concentrations were determined in control and irradiated rats using jejunal and ileal segments ( $5 \mathrm{~cm}$ in length) adjacent to those collected for MPO activity and histology determinations. Tissues were dissected on ice and scparated into muscular and mucosal layers, weighed and boiled in 20 vols (w/v) of $0.1 \mathrm{~N} \mathrm{HCl}$ for $10 \mathrm{~min}$. They were then homogenized using a T25 Ultraturrax and centrifuged at $1700 \mathrm{~g}$ for $10 \mathrm{~min}$. The supernatants were stored at $-20^{\circ} \mathrm{C}$ for later neutralization and radioimmunoassay (RIA). Neutralization of tissue extracts was performed by addition of $\mathrm{NaOH}(1 \mathrm{M})$ to a final $\mathrm{pH}$ of 7. GGRP immunoreactivity was directly detcrmined on the neutralized tissuc homogenate supernatant according to a RIA protocol (Peninsula Laboratories, St Helens, UK) using rabbit antiserum.
The RIA for GGRP was performed using rabbit antibody RAS 6006 raised against rat CGRP. The sensitivity of this assay is $3 \mathrm{pg} /$ tube. In brief, aliquots of $100 \mu \mathrm{l}$ of rehydrated antiserum were incubated for $16-24 \mathrm{~h}$ at $4^{\circ} \mathrm{C}$ with standards or the unknown samples in a final volume of $200 \mu \mathrm{l} ; 15000 \mathrm{cpm} /$ $100 \mu \mathrm{l}$ of ${ }^{125} \mathrm{I}-\mathrm{CGRP}$ (specific activity: $1717 \mathrm{Gi}$ / mmole) was added and incubated once again for $16-24 \mathrm{~h}$ at $4^{\circ} \mathrm{C}$. To perform the second antibody separation, $100 \mu \mathrm{l}$ of dilute goat anti-rabbit IgG serum (GARGG 500) and $100 \mu$ l of dilute normal rabbit serum (NRS 500) were added. Precipitates were allowed to form for $2 \mathrm{~h}$ at room temperature, then $500 \mu \mathrm{l}$ of RIA buffer was added. RIA tubes were centrifuged at $1700 \mathrm{~g}$ for $20 \mathrm{~min}$ at $4^{\circ} \mathrm{C}$. Then the supernatants were discarded by aspiration and the ${ }^{125} \mathrm{I}$ radioactivity in the pellet was determined in a gamma counter (Cobra II auto-gamma, Packard, Rungis, France).

\subsection{Statistical analysis}

Results are expressed as means 土SEM. Multiple comparisons were performed with non-parametric analysis of variance and followed by Dunn's multiple comparison post-test. Statistical significance was accepted if $p<0.05$.

\section{Results}

\subsection{Effects of irradiation}

Following $10 \mathrm{~Gy}$ abdominal irradiation, food intake was markedly decreased by $54.8 \pm 6.2 \%$ and $88.2 \pm 4.0 \%$ on days 1 and 3 respectivcly $(n=4)$. This attenuated food intake was associated with a reduction in body weight $(7.7 \pm 0.6 \%$ and $9.3 \pm 0.8 \%$ decrease on days 1 and 3 , respectively; $n=6$ ).

3.1.1. Mast cell and siructural histology. In the two intestinal segments investigated, the number of histologically detectable mucosal mast cells decreased dramatically $(-95 \%)$ on the first day after irradiation and mast cells were nearly undetectablc on the third day (figure 1). Routine histology revealed neither destruction of the continuity of the epithelium nor any alterations characteristic of inflammation of both mucosa and muscular layer of the small intestine on day 1 and on day 3. In the small intestine there was a thrce-fold increase in apoptotic cells in the crypts in vehicle irradiated group (18.3 \pm 1.7 apoptotic cells $/ 50$ crypts; $n=12, p<0.05$ ) as compared with the vehicle sham-irradiated group $(5.9 \pm 1.1$ apoptotic cells/50 crypts) at 1 day after irradiation. However 

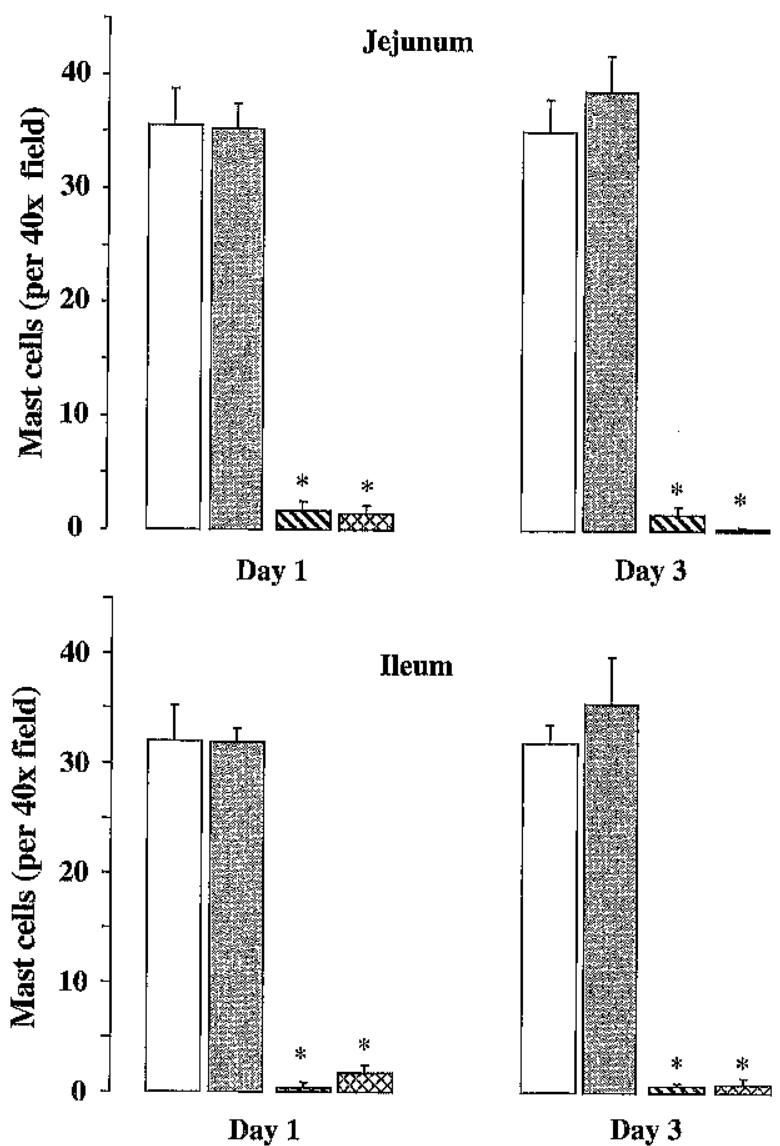

Day 3
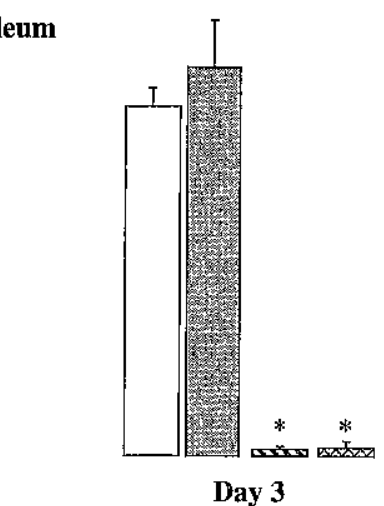

Day 3

Figure 1. Effects of vehicle and capsaicin treatment on mast cell numbers 1 and 3 days after abdominal irradiation. $\square$ vehicle sham-irradiated rats; $\square$ capsaicin shamirradiated rats; $\mathbb{\mathbb { V }}$ vchicle-irradiatcd rats; ${ }^{2}$ capsaicinirradiated rats. (means $\pm \mathrm{SEM}, n=6$ ). * * $p<0.05$, significantly different from corresponding control values.

at 3 days the number of apoptotic cells was similar to vehicle sham-irradiated group $(6.2 \pm 0.6, n=6)$.

3.1.2. MPO activity. On the first day after irradiation, no significant change in MPO activity was observed at the two levels investigated. On the third day, MPO activity dramatically increased at the two levels, the greatest increase (32-fold) being observed in the jejunum $(318.5 \pm 55.0$ versus $10.1 \pm 2.3 \mathrm{U} / \mathrm{g}$ protein; figure 2).

\subsubsection{GGRP content. On day 1, jejunal mucosa CGRP} levels were increased $(p<0.05$ versus control; table 1). At this time no changes were seen in ileal CGRP content (table 1). However, on the third day after irradiation, CGRP content significantly increased in small intestine (jejunum and ileum) both in mucosa and muscle layers $(p<0.05$ versus control).


Figure 2. Effects of systemic and capsaicin treatment on myeloperoxidase (MPO) activity I day and 3 days after abdominal irradiation. $\square$ vehicle shann-irradiated rats; - capsaicin sham-irradiated rats; $\mathbb{N}$ vehicle-irradiated rats; capsaicin-irradiated rats. (means \pm SEM, $n=6$ ). $* p<0.05$, significantly different from corresponding control valucs. $\dagger p<0.05$, significantly different from vehicle-irradiated group values.

\subsection{Effects of irradiation after sensory denervation}

Gapsaicin pretreatment did not significantly modify the irradiation-induced decreases in food intake $(6.8 \pm 0.9 \%$ and $8.0 \pm 1.1 \%$ on days 1 and 3 respectively; $n=4$; means $\pm \mathrm{SEM}$ ) or body weight $(51.01 \pm 4.6 \%$ and $87.6 \pm 2.5 \%$ on days 1 and 3 , respectively, after irradiation; $n=6$, means \pm SEM).

3.2.1. Mast cells and routine histology. The marked decrease in the number of mast cells observed in the small intestine on the first and third days after irradiation was not significantly modified by capsaicin pretreatment (figure 1). As observed in vehicletreated rats, neither epithelial disruption nor marked inflammatory processes were detected in either the mucosa or external muscle layers on days 1 and 3 after irradiation in capsaicin-treated rats. Capsaicin pretreatment alone did not cause apoptosis in the small intestine and levels were similar to those described in the previous section $(5.9 \pm 0.9, n=12$, in the capsaicin sham-irradiated group and $5.9 \pm 1.1$, 
Table 1. Concentrations of CGRP in mucosa and musclc layers of jejunum and ilcum, 1 and 3 clays after exposure to 10 Gy abdominal irradiation or sham-irradiation in caspaicin- and vehicle-treated groups.

\begin{tabular}{|c|c|c|c|c|}
\hline & \multicolumn{2}{|c|}{ Jejunum } & \multicolumn{2}{|c|}{ Ileam } \\
\hline & mucosa CGRP & muscle CGRP & mucosa CGRP & musclc GGRP \\
\hline \multicolumn{5}{|c|}{ Sham-irradiated animals } \\
\hline Control vehicle & $6.5 \pm 0.5$ & $17.0 \pm 1.6$ & $5.8 \pm 0.5$ & $16.8 \pm 0.9$ \\
\hline Control caspaicin & $8.8 \pm 0.5$ & $9.2 \pm 0.3^{*}$ & $6.5 \pm 0.5$ & $9.3 \pm 0.3^{*}$ \\
\hline \multicolumn{5}{|l|}{ Irracliated animals } \\
\hline Day 1 vehicle & $20.5 \pm 2.2 \dagger$ & $15.1 \pm 1.7$ & $10.1 \pm 1.0$ & $14.5 \pm 0.7$ \\
\hline Day 1 caspaicin & $8.6 \pm 1.4^{*}$ & $14.1 \pm 0.6 \dagger$ & $6.3 \pm 0.9$ & $15.8 \pm 0.4+$ \\
\hline Day 3 vehicle & $17.3 \pm 2.6 \dagger$ & $26.5 \pm 0.6 \dagger$ & $15.6 \pm 1.7 \dagger$ & $20.8 \pm 1.1 \uparrow$ \\
\hline Day 3 caspaicin & $24.0 \pm 2.6$ & $15.9 \pm 0.7^{*}+4$ & $12.5 \pm 1.5^{\dagger}$ & $16.9 \pm 0.4 *$ \\
\hline
\end{tabular}

Values are means $\pm \mathrm{SEM}, n=6(\mathrm{pmol} / \mathrm{g}$ tissue).

* $p<0.05$, caspaicin treatment compared with vehicle.

$\uparrow p<0.05$, irradiated animals compared with sham-irradiated animals.

$n=12$, in the vehicle sham-irradiated group). Capsaicin treatment (22.9 \pm 3.0 apoptotic cells/50 crypts; $n=12$ ) did not modify the increased number of apoptotic cells observed in vehicle irradiated rats $(18.3 \pm 1.7$ apoptotic cells $/ 50$ crypts; $n=12)$ from the first day after irracliation.

3.2.2. $M P O$ activity. In capsaicin-treated rats on the first day after irradiation, in contrast to that observed in vehicle animals, there was a significant increase (4.5- and 3-fold) in MPO activity (figure 2). In addition, in the jejunum, the increase in MPO activity was different from both capsaicin sham-irradiated and vehicle irradiated rats. However, the increase in MPO activity observed on the third day after irradiation in vehicle rats was not significantly modified by capsaicin pretreatment (figure 2).

3.2.3. CGRP content. Capsaicin pretreatment significantly decreased levels of CGRP in the muscle layers of both jejunum and ileum as compared with control vehicle values $(p<0.05)$, but not in the mucosal layer. One day after irradiation, pretreatment with capsaicin significantly $(p<0.05)$ decreased GGRP content in jejunum mucosa compared with vehicle pretreatment; in ileum mucosa, CGRP concentrations tended to be lower in the capsaicin rats than in vehicle animals, but this decrease did not reach statistical significance.

Three days after irradiation, there was no difference betwcen the capsaicin group and the vehicle group in the mucosa of both jejunum and ileum; in contrast, CGRP contents in muscle layers were significantly decreased $(p<0.05)$ in capsaicin group com- pared with vehicle group at the two sites investigated (table 1).

\section{Discussion}

The present study provides evidence that a single dose $(10 \mathrm{~Gy})$ of abdominal irradiation increases MPO activity and concentrations of CGRP and decreases mast cell numbers in the small intestine. The routine histology did not detect any epithelial disruption 1 . days and 3 days after irradiation, but number of apoptotic cells increased in crypts of the small intestine 1 day after irradiation.

The absence of epithelial damage, which agrecs with observations of others (Empey et al. 1992, MacNaughton et al. 1997) does not exclude functional alterations of the mucosa. The appearance of apoptotic cells is in agreement with other studies (Arai et al. 1996, Ruifrok et al. 1997) as is the rapid disappearance of mast cells (Cummins et al. 1989, Harari et al. 1994). However no infiltration of neutrophils was seen histologically at any time, which did not correlate with increased MPO activity at 3 days. Buell and Harding (1989) found an increase in neutrophil infiltration within $12 \mathrm{~h}$ after $10 \mathrm{~Gy}$ abdominal irradiation in rats. At $24 \mathrm{~h}$, in agreement with the present study, there was no evidence of infiltration. In contrast, in other models of intestinal inflammation, such as that provoked by administration of trinitrobenzenosulphonic acid (TNBS), acute inflammatory responses have been obscrved with an important increase of neutrophil infiltration at the site of TNBS administration (Miller et al. 1993). In the present study, the irradiation was external and was not to a specifically localized site of the gut, like 
TNBS-induced administration, but over a large abdominal field. Infiltration of neutrophils was observed histologically only infrequently on $5-\mu \mathrm{m}$ sections and so, it is difficult to compare such measurements to those of MPO activity which uses a much larger tissue sample. However, no change in small intestine MPO activity has been observed $24 \mathrm{~h}$ and $4: 8 \mathrm{~h}$ after whole-body irradiation (MacNaughton et al. 1994, MacNaughton et al. 1998) and, moreover, a decrease in MPO activity has been reported at the colonic level $48 \mathrm{~h}$ after irradiation (MacNaughton et al. 1998). On the other hand, an increased jejunal MPO activity has been shown $2 \mathrm{~h}$ post-irradiation (MacNaughton and Prud'homme-Lalonde 1995). Thus it seems that data concerning changes in MPO after irradiation are still controversial and the differences between studies seem to depend upon the intestinal segment, the mode of irradiation and the time at which the observations were performed.

Destruction of sensory afferents by capsaicin did not modify the mast cell depletion observed after irradiation. According to the anatomical relationships between sensory neurons and mast cells, and the well-known ability of substance $\mathrm{P}$, a major tachykinergic mediator of sensory afferents, to degranulate mast cells (Maggi 1997), one can speculate that substance $\mathrm{P}$, which is rapidly released from the intestinal wall after irradiation (Esposito et al. 1996) could be responsiblc in part for the irradiationincluced mast cell degranulation. Such an hypothesis is not supported by our results showing that mast cell depletion occurs independently of the sensory innervation. Similarly, Cummins et al. (1994) observed that mast cell degranulation associated with weaning in rats was not modificd after destruction of sensory afferents by capsaicin.

In contrast to the marked mast cell depletion no change in MPO activity occurred on the first day post-irradiation. However, a significant increase of MPO activity was found in capsaicin-treated animals, suggesting a role for sensory afferents in the early stage of irradiacion-induced inflammation. A protective role of sensory neurons has been observed in different animal models where inflammation was induced by compounds such as I'NBS (Reinshagen et al. 1996, Mazelin et al. 1998a) and sodium dextran sulphate (Domek et al. 1997) or ricin (Shea-Donohue et al. 1997). The main mediators of sensory afferents are CGRP and tachykinins. Substance $\mathrm{P}$ is released from extrinsic and intrinsic ncurons during an experimental inflammation in animals (Reinshagen et al. 1995) and the number of substance P nerve fibres is increased in ulcerative colitis in humans (Keranen et al. 1995). However, following total-body irradiation of rats tissue levels of substance $\mathrm{P}$ were decreased in the ileum (Esposito et al. 1996).

In the small intestine CGRP is localized in both extrinsic and intrinsic neurons (Sternini et al. 1987) and measurement of GGRP levels in intestinal tissue whilst providing tissue concentration of the peptide does not relate directly to neuronal activity. Nevertheless, the increase of tissue CGRP concentrations 1 day after irradiation may reflect either blocked GGRP release, increased synthesis or decreased catabolism. Consequently, we suggest that, according to the increase of GGRP levels in jejunum 1 day after irradiation in vehicle-treated animals compared to the decrease seen in capsaicin-treated animals 1 day after irradiation, the effect of sensory afferents against irradiation-induced inflammation may depend in part on CGRP at this time. In support of this, a recent study showed an increase in CGRP-immunoreactive nerve fibres in mesenteric arteries in rats, $24 \mathrm{~h}$ after a whole-body irradiation; the authors suggested a protective function of CGRP against irradiation (Zhang et al. 1998).

In contrast, on the third day after irradiation we did not observe any protective action of sensory afferents on intestinal inflammation as assessed by MPO activity and it may be postulated that the protective action of afferents is overwhelmed by several pro-inflammatory factors. Finally, our study shows that ablation of sensory nerves by capsaicin does not affect the marked enhancement of mucosal apoptosis observed on the first day after irradiation. This suggests that intestinal scnsory innervation may not be involved in the protection of the intestinal mucosa against radiation-induced apoptosis. Some data for a role of innervation in apoptosis have been already reported for organs or tissues other than the digestive tract. For cxample, in newborn rats some muscle fibres in developing striated muscle undergo apoptosis due to lost innervation resulting from the retraction of nerve terminals (Trachtenberg 1998). Moreover, experimental denervation induces a sevcral-fold increase in the magnitude of fibre apoptosis. One important property of CGRP is vasodilatation; thus a reduced release may effectively create tissue anoxia and subsequent apoptosis of intestinal epithelial cells as has been demonstrated in cases of ischaemia-reperfusion in mice (Farber et al. 1999). Despite the increase in CGRP levels after irradiation, the irradiation-induced apoptosis does not seem to be associated with GGRP, since capsaicin treatment, which destroys GGRP immunoreactive sensory neurons, did not modify irradiation-induced apoptosis.

In conclusion, sensory afferents do not play a major protective role in the early ( 1 day) mucosal alterations induced by abdominal irradiation, since 
only MPO activity was slightly, yet significantly, increased at this time in capsaicin-treated rats while other parameters, such as apoptosis and mast cell numbers remained unchanged.

\section{Acknowledgements}

We gratefully acknowledge C. Maubert for helpful assistance, and Q. Chau and F. Trompier for performing irradiations. This work was supported by Electricité de France (EDF).

\section{References}

Arai, T., Kida, Y., Harmon, B. V. and Gob, G. C., 1996, Expression and localization of clusterin mRNA in the small and large intestine of the irradiated rat : its relationship with apoptosis. Intemational foumal of Radiation Biology, 69, 547-553.

Bradley, P. P., Priebat, D. A., Christensen, R. D. and Rothstein, G., 1982, Measurement of cutaneous inflammation: estimation of neutrophil content with an enzyme marker. Foumal of Investigative Dermatology, 78, 206-209.

Bueld, M. G. and Harding, R. K., 1989, Proinflammatory effects of local abdominal irradiation on rat gastrointestinal tract. Digestive Diseases and Sciences, 34, 390-399.

Chiun, H., Sasakx, M., Fujryama, Y. and Bamba, T., 1997, Effect of enteral glutamine on intestinal permeability and bacterial translocation after abdominal radiation injury in rats. Joumal of Gastroenterology, 32, 189-95.

Conard, R. A., 1956, Some effects of ionizing radiation on the physiology of the gastrointestinal tract: a review. Radiation Research, 5, 167-188.

Cummins, A. G., Antoniou, D. and Thompson, F. M., I994, Neuropeptide depletion by capsaicin does not prevent mucosal mast cell activationin the rat at weaning. Immunology and Cell Biology, 72, 230233.

Cummins, A. G., Munro, G. H., Huntley, J. F., Miller, H. R. and Fergusson, A., 1989, Separate effects of irradiation and of graft-versus-host reaction on rat mucosal mast cells. Gut, 30, 355-360.

Domek, M. J., Blagkman, E. I., Kao, J., Zhang, X. Y., Iwata, F., Seno, K. and Leung, F. W., 1997, Functional ablation of afferent nerves aggravatcs dextran sulphate sodium-induced colonic damage in rats. Foumal of Gastroenterology and Hepatology, 12, 698-702.

Empey, L. R., PAPr, J. D., JeWell, L, D, and Fedorak, R. N., 1992, Mucosal protective effects of vitamin $\mathbf{E}$ and misoprostol during acute radiation-induced enteritis in , rats. Digestive Diseases and Sciences, 37, 205-214.

Ericison, B. A., Otrerson, M. F., Moulder, J. E. and Sarna, K., 1994, Altered motility causes the early gastrointestinal toxicity of irradiation International Fournal of Radiation, Oncology, Biology, Physics, 28, 905-912.

Esposito, V., Linakd, C., Maubert, C., Aigueperse, J. and Gourmedon, P., 1996, Modulation of gut Substance P after whole-body irradiation. A new pathological feature. Digestive Diseases Science, 41, 20702077.

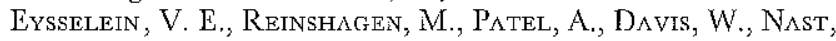
C. and Sternini, C., 1992, Calcitonin gene-related peptide in inflammatory bowel discase and expcrimentally induced colitis. Annals New Fork Academy of Sciences, 657, 319-327.

Farber, A., Connors, J. P., Friedlander, R. M., Wagner, R. J., Poweli, R. J. and Cronenwett, J. L., 1999, A specific inhibitor of apoptosis decreases tissue injury after intestinal ischcmia-reperfusion in mice. Foumal of Vascular Surgery, 30, 752-760.

Forsgren, S., Hocherfelt, U., Norrgard, O., Henriksson, R. and Franzen, L., 2000, Pronounced substance P innervation in irradiation-induced enteropathy - a study on human colon. Regulatory Peptides, 88, 1-13.

François, A., Aigueperse, J., Gourmelon, P., MacNaughton, W. K. and Griffiths, N. M., 1998, Exposure to ionizing radiation modifies neurally evoked electrolyte transport and some inflammatory responses in rat colon in vitro. Intemational Foumal of Radiation Biology, 73, 93-101.

GAmse, R., 1982, Capsaicin and nociception in the rat and mouse. Possible role of substance P. Naunyn-Schmiedeberg's Arclives of Pharmacology, 320, 205-216.

Gunter-Smith, P. J., 1986, Gamma radiation affects active electrolyte transport by rabbit 1leum: basal $\mathrm{Na}$ and $\mathrm{Cl}$ transport. American Joumal of Physiology, 250, G540 - G545.

Harari, Y., Kester, D., Travis, E., Wallage, J. and Castro, G., 1994, Intestinal anaphylaxis: radiation-induced suppression. American foumal of Physiology, 267, G709-G715.

Hirsarowitz, L. and RoDE, J., 1991, Changes in neurons, neuroendocrine cells and nerve fibres in the lamina propria of irradiated bowel. Virchowes Archives A Pathology Anatomy Histopathology, 418, 163-168.

Hockerfelt, U., Henriksson, R., Franzex; L., Norrgard, O. and Forsaren, S., 1999, Irradiation induces marked immunohistochemical expression of vasoactive intestinal peptide in colonic mucosa of man. Digestive Diseases Science, 44, 393-401.

Hockerfelt, U., L., F., KJorell, U. and Forsgrein, S., 2000, Parallel increase in substance $\mathrm{P}$ and VIP in rat duodenum in response to irradiation. Peptides, 21, 271-281.

Holzer, P., 1991, Capsaicin: cellular targets, mechanisms of action, and selectivity for thin sensory neurons. Phamacological Reviewes, 43, 143-201.

Holzer, P, 1998, Implications of tachykinins and calcitonin gene-related peptide in inflammatory bowel disease. Digestion, 59, 269-283.

Keates, A. C., Casiagliyolo, I., Quv, B., Nikul.asson, S., Sengupta, A. and Pothoulakis, C., 1998, CGRP upregulation in dorsal root ganglia and ilcal mucosa during Clostridium diffcile toxin A-induced enteritis. American 7oumal of Physiology, 274, G196-G202.

Keranen, U., Kiviluo'o, T., Jarvinen, H., Back, N., KivilaAkso, E. and Sornila, S., 1995, Changes in substance P-immunoractive immervation of human colon associated with ulcerative colitis. Digestive Diseases Science, 40, 2250-2258.

MacNaughton, W. K, and Prud'hommi-Lalonde, L., 1995, Exposure to ionizing radiation alters vasoreactivity in ral jejunum ex vivo. Canadian foumal of Physiology and Phamnacology, 73, 699-705.

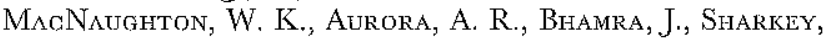
K. A. and Muluer, M. J. S., 1998, Expression, activity and ccllular localization of inducible nitric oxide synthase in rat ileum and colon post-irradiation. International fournal of Radiation Biology, 74, 255. 264.

Magnaughton, W. K., Leagh, K. E., Prud'riomml-Lalonoe, I. and Harding, R. K., 1997, Exposurc to ionizing radiation increases responsiveness to neural secretory 
stimuli in the ferret jejunum in vitro. International Foumal of Radiation Biology, 72, $219-226$.

Magnaughton, W. K., Lench, K. E., Prud'homme-Lalonde, L., Ho, W. and Sharkey, K. A., 1994, Ionizing radiation reduces neurally evoked clcctrolyte transport in rat ileum. through a mast cell-dependent mechanism. Gastroenterology', 106, 324-335.

MAGGI, C. A., 1997, The effects of tachykinins on inflammatory and immune cells. Regulatory Peptides, 78, 75-90.

Mazelin, L., Theodorou, V., Fioramon't', J. and Bueno, I., 1999, Vagally dependent protective action of calcitonin gene-related peptide on colitis. Peptides, 20, 1367-1374.

Mazelin, L., Theodorou, V., Moré, J,, Edmonds-Alt, X., Froramontr, J. and Buéno, L., 1998b, Comparative effects of nonpepticle tachykinin receptor antagonists on experimental gut inflammation in rats and guinea-pigs. Life Science, 63, 293-304.

' Mazelin, L., Theodorou, V., Moré, J., Fioramonti, J. and Búno, L., 1998a, Protective role of vagal afferents in experimentally-induced colitis in rats. Foumal of Autonomic Nerous System, 73, 38-45.

MaCafferty, D. M., Wallace, J. L. and Sharkey, K. A., 1997, Effects of chemical sympathectomy and sensory nerve ablation on experimental colitis in the rat. American Joumal of Physiology, 272, G272-G280.

Merritt, A. J., Jones, L. S. and Potten, C. S., 1996, Apoptosis in murine intestinal crypts. In Techniques in Apoptosis, eclited by T. G. Cotter and S. G. Martin (London: Portland press), pp. 269-299.

Miller, M. J. S., Sadowsma-Krowicka, H., Jeng, A. Y., Chotinaruemol, S., Wong, M., Clark, D. A., Ho, W. and Sharkey, K. A., 1993, Substance P levels in experimental ileitis in guinea pigs: effects of misoprostol. American. Fournal of Physiology, 265, G321. G330.

Potten, C. S. and Grant, H. K., 1998, The relationship between ionizing radiation-induccd apoptosis and stem cells in the small and large intestine. British Foumal of Cancer, 78, 993-1003.

Reinshagen, M., Adier, G. and Eysselein, V. E., 1995, Substance P' gene expression in acute cxperimental colitis. Regulatory Peplides, 53-58.

Reinshagen, M., Flamic, G., Ernst, S., Geerling, I., Wong, H., Walsh., J., Eysselein, V. and Adler, G., 1998, Calcitonin gene-related peptidc mediates the protective effect of sensory nerves in a model of colonic injury. Joumal of Phamacology and Experimental Therapeutics, 286, $657-661$.
Reinshagen, M., Patel, A., Sottili, M., French, S., Sternind, C. and Eysselein, V. E., 1996, Action of sensory neurons in an experimental rat colitis model of injury and repair. American foumal of Physiology, 270, G79-G86.

Roberts, I. S., Jones, C. J. and StoddarT, R. W., 1990, Lectin histochemistry of the mast cell: heterogeneity of rodent and human mast cell populations. Histochemical foumal, 22, $73 \cdot 80$

Ruifrok, A. C. C., Mason, K. A., Lozano, G. and Thames, H. D., 1997, Spatial and temporal patterns of expression of epidermal growth factor, transforming growth factor alpha and transforming growth factor beta $1-3$ and their receptors in mouse jejunum after radiation treatment. Radiation Research, 147, 1--12.

Sedgwick, D. M. and Ferguson, A., 1994, Dose-response studies of depletion and repopulation of rat intestinal mucosal mast cells after irradiation. International foumal of Radiation Biology, 65, $483 \cdots 495$.

SHARKEy, K. A, 1992, Substance P and calcitonin gene-related pepticle (CGRP) in gastrointestinal inflammation. Annals New Tork Academy of Sciences, 664, 425 -442.

Shea-Donorie, T., Goldhill, J. M., Montcalm-Mazzilli, E., Colleton, C., Pineiro-Garrero, V. M. and Sjogren, R. W., 1997, Role of sensory afferents in the myoelectric response to acute enteric inflammation in the rabbit. American Joumal of Physiology, 273, G44.7-G455.

Sternini, C., Reeve, J. R. and Bregha, N., 1987, Distribution and characterization of Calcitonin gene-related peptide immunoreactivity in the digestive system of normal and capsaicin-treated rats. Gastroenterology, 93, 852-862.

TracittenberG, J. T., 1998, Fibers apoptosis in developing rat muscles is regulates by activity, neuregulin. Developmental Biology, 196, 193-203.

Wallage, J. I., MacKnigirl', G. W. and Befus, A. D., 1992, Capsaicin-induced hyperemia in the stomach: possiblc contribution of mast cells. American Jounal of Physiology, 263, G209-G214.

Yeoh, E., Horowl'z, M., Russo, A., Muecke, T., Robb, T., Madnox, A. and Chatterton, B., 1993, Eflect of pelvic irradiation on gastrointestinal function: a prospective longitudinal study. American Journal of Medicine, 95, 397406.

Zhang, C., CaI, W., Ili, Y., Huang, W. and Su, H., 1998, Quantitative analysis of calcitonin gene-related peptide and ncuropeptide $\mathrm{Y}$-immunoreactive nerve fibers in mesenteric blood vessels of rats irradiated with cobalt-60 gamma rays. Radiation Research, 149, 19-26. 